\title{
Assessment of influence of environmental factors on economic indexes of agrarian pro-duction
}

\section{Shkuratov 0.}

Institute of agroecology and nature management of NAAS, Metrolohichna Str., 12, Kyiv, 03143, Ukraine; e-mail: shkuratov@nas.gov.ua

The purpose. To justify theoretical-methodical bases of assessment of influence of some environmental factors on efficiency of agrarian production. Procedure. By means of correlation-regression analysis they select environmental factors which have the greatest influence on economic indexes of agrarian production in Ukraine. Results. Mathematical dependences are gained of change of volumes of production of gross output of agriculture on these factors. Conclusions. The offered equations of dependence of economic and ecological indexes enable to monitor ecological state of agrarian production during its development.

Key words: agrarian production, efficiency, assessment, effect, environmental factors.

Formulation of the issue. Sustainable development of the agrarian sector, stable economic growth of agricultural production, which does not lead to significant degradation changes of the environment, can be ensured by bringing the economic interests of agricultural producers in line with the environmental requirements of environmental protection. In view of this, the issue of increasing the efficiency of agricultural production due to its ecologization, starting with the organization of rational use of natural resources as the main means of production, becomes of particular relevance. Therefore, a very important element of the economic activity of agrarian enterprises is the consideration of environmental factors in order to increase the economic efficiency of agricultural production and preservation of agro ecosystems.

An analysis of recent research and publications on the topic under study. Theoretical and methodical approaches to the assessment of the mutual influence of agricultural activity and the environment were investigated in the works by O.F. Balatskyi, L.M. Hranovska, N.V. Zinovchuk, V.I. Kazakevych, O.I. Karpishchenko, V.F. Kolmykov, M.M. Ksenofontova, L.H. Melnyk, Ye.H. Lysenko etc. O.M. Borodina, Yu.O. Lupenko, Ye.V. Mishenin, P.T. Sabluk, A.M. Stelmashchuk, O.V. Ulianchenko, O.I. Furdychko, O.V. Khodakivska etc. made an important contribution to solving the challenges of increasing the ecological and economic efficiency of agrarian production. In their writings, scientists have quite substantially covered the issues of the impact of agrarian production on the environment. However, the formulation of specific scientific recommendations regarding the impact of environmental factors on the efficiency of agricultural production has not paid much attention.

The purpose of the study is to substantiate the theoretical and methodological principles of assessing the impact of certain ecological factors on the efficiency of agrarian production.

Research results. The final result of agricultural production depends on many factors, the most important of which is considered ecological, which characterizes the environment and conditions for the production of agricultural products, and also plays a decisive role in the development of rural areas. The variety of factors that affect the economy of agricultural production, indicates the complexity of causal relations in the process of interaction between agrarian production and the environment, between economic and environmental indicators that characterize the performance of enterprises [1, p. 55; 2].

Summarizing the effect of economic consequences (which can more or less be estimated) of the negative impact on the basis of agricultural production - plant growing, one can distinguish the main features of their manifestation:

- disturbance of balance between agroecosystems (arable land, hayfields, pasture lands), forest and water; 
- the development of wind and water erosion of land (according to expert estimates, the loss of agricultural production from erosion exceeds 9-12 million tons of grain units, thus the ecological and economic losses as a result of erosion exceed 10 billion dollars annually [3]);

- a high volume of mineral fertilizers and a decrease in organic matter (the total loss of humus through mineralization is $32-33$ million tons annually, which is equivalent to $320-330$ million tons of organic fertilizers, and environmental and economic losses through erosion exceed 9.1 billion UAH [4, p. 27]);

- deviations of soil moisture from optimal norms by $10 \%$, which leads to a decrease in the yield of some crops up to $20-25 \%$ [5];

- yields on re-saline soils (due to the use of low quality water for irrigation and violation of scientifically grounded irrigation regimes and agrotechnical measures) is significantly reduced, in particular: cereals 1.5-2 times; tilled - 3-4; vegetable - almost 5 times [5].

However, it is possible to highlight the positive effect of some environmental factors on the efficiency of agricultural production, in particular, increasing the level of cultivation (ie, changing the landscape structure) increases the area of arable land, and, consequently, an increase in gross output per unit of agricultural land.

To analyze the impact of environmental factors on the efficiency of agricultural production, we propose to set a dependence between environmental and economic indicators by means of estimating various estimates and statistics. Thus, it is recommended to apply economic-mathematical methods of analysis, which enable to identify the relations between factor and result indicators, in particular, correlation-regression analysis [6, p. 197]. This analysis provides the identification of the main factors of dependence, reflecting the quantitative assessment of their degree of communication.

The research was conducted on the statistical indicators of agricultural production of Ukrainian regions [7; 8; 9] and estimated personal data. The list of signs of the ecological state of the agrarian sector has a wide spectrum, which is described by a set of indicators. But let's consider only those that really reflect the influence of environmental factors on the economic indicators of agricultural production. Among the main indicators of assessment of environmental factors there were considered the following: coefficient of ecological stability of the territory; coefficient of anthropogenic loading territory; the erosion of lands, the introduction of organic fertilizers per 1 ha, the introduction of mineral fertilizers per 1 ha, the use of pesticides per 1 ha, ecological and agrochemical assessment of land and humus content. These indicators, in our opinion, reflect the general ecological state of crop production. As a result of the most characteristic of the efficiency of agricultural production, the volume of gross agricultural output (at constant prices in 2010) per 100 hectares of agricultural land was selected.

Using correlation-regression analysis, we found the dependence between the indicators characterizing environmental factors and the volumes of gross agricultural output per 100 hectares of agricultural land in the regions of Ukraine (data for 2011-2015), which is described by the linear equations:

$$
y=a x+b
$$

where $y$ - the volume of gross agricultural products (at constant prices of 2010), ths. UAH;

$x$ - indicators of environmental factors of agricultural production;

$a, b$-constant coefficients, the magnitudes of which are given in Tab. 1.

Table 1. Numerical values of the regression coefficients of the environmental factors influence on the gross agricultural output in Ukraine

\begin{tabular}{|l|c|c|c|c|}
\hline \multirow{2}{*}{ Indicator } & \multicolumn{2}{|c|}{$\begin{array}{c}\text { The value of the coefficients } \\
\text { for the linear equation }\end{array}$} & \multirow{2}{*}{$\begin{array}{c}\text { Correlation } \\
\text { coefficient }\end{array}$} & $\begin{array}{c}\text { Determination } \\
\text { coefficient }\end{array}$ \\
\cline { 2 - 3 } & $\mathbf{a}$ & $\mathbf{b}$ & 0.44 & 0.19 \\
\hline $\begin{array}{l}\text { Coefficient of environmental stability, } \\
\text { units. }\end{array}$ & 7.6324 & 359.31 & -0.40 & 0.16 \\
\hline $\begin{array}{l}\text { Coefficient of anthropogenic loading, } \\
\text { units. }\end{array}$ & -308.44 & 1714.7 & -0.56 & 0.31 \\
\hline Land erosion,\% & -6.1977 & 891.57 & 0.71 & 0.50 \\
\hline Pesticide load, $\mathrm{kg} / \mathrm{ha}$ & 314.73 & 273.84 & 0.70 & 0.49 \\
\hline Chemical load, $\mathrm{kg} / \mathrm{ha}$ & 4.6671 & 257.36 & & \\
\hline
\end{tabular}




\begin{tabular}{|l|c|c|c|c|}
\hline $\begin{array}{l}\text { Volume of introduction of organic } \\
\text { fertilizers, } \mathrm{t} / \mathrm{ha}\end{array}$ & 196.87 & 548.44 & 0.50 & 0.25 \\
\hline $\begin{array}{l}\text { Ecological-agrochemical estimation of } \\
\text { lands, score }\end{array}$ & -7.4153 & 1040.9 & 0.42 & 0.18 \\
\hline Humus content in the soil, \% & -64.54 & 855.66 & 0.35 & 0.12 \\
\hline
\end{tabular}

Source: the author's calculations.

The strongest connection among the analyzed factors is between the volume of gross agricultural output and pesticide burden (i.e. the volume of pesticide using by agricultural enterprises, $\mathrm{kg} / \mathrm{ha}$ ). Fig. 1 shows a point graph and a linear trend of the relationship.

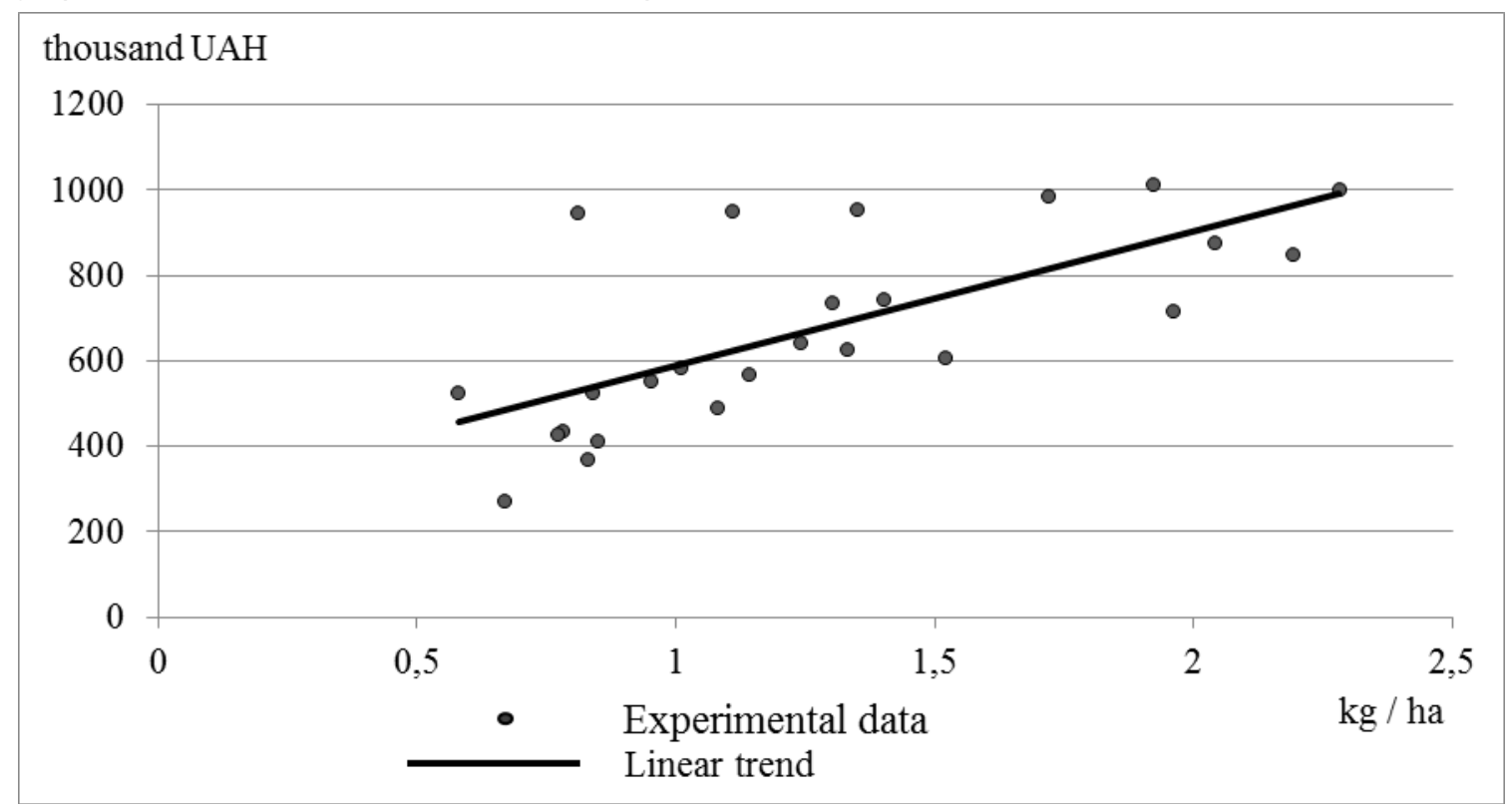

Fig. 1. Correlation dependence of gross agricultural output and pesticide load

Source: author's calculations.

According to the linear regression, the Pearson correlation coefficient (0.71) shows an average link and a direct dependents between them. The coefficient of determination $(0,50)$ indicates that $50 \%$ of all changes in the volume of gross agricultural output are because of changes in the volumes of pesticides using by agricultural enterprises. That means, that the accuracy of the selection in the regression equation is sufficient. The linear regression shows (with a probability of 50\%) that the increasing in the use of pesticides by agricultural enterprises per $1 \mathrm{~kg} /$ ha corresponds to an increassing in the volume of gross agricultural output by 588.57 thousand UAH per 100 hectares of agricultural land.

For a more detailed analysis of the influence of these factors (except of the less influential ones) on the gross agricultural output, we constructed plural linear regression. The results showed the existence of a close communication between the factor and the resultant characteristics (coefficient of multiple correlation $\mathrm{R}$ $=0.83$ ). The obtained equation of regression has the form:

$$
Y=298,5+200,48 X_{1}+1,69 X_{2}-2,06 X_{3}+67,76 X_{4} \text {, }
$$

де $Y$ - the volume of gross agricultural production per 100 hectares of agricultural land (in constant prices in 2010), thousand UAH;

$X_{1}$ - pesticide load, $\mathrm{kg} / \mathrm{ha}$;

$X_{2}-$ chemical load, $\mathrm{kg} / \mathrm{ha}$ of active ingredient;

$X_{3}-$ erosion of lands, \%;

$X_{4}-$ volume of organic fertilizer application, $\mathrm{t} / \mathrm{ha}$. 
The value of the determination coefficient $\left(R^{2}=0.68\right)$ indicates that $68.0 \%$ of the variation of the dependent variable is because of introduced factors in the correlation model, and the rest - by other nonaccounted factors. Determination of the influence of environmental factors on the economic efficiency of agricultural production enables to the system of management of agrarian nature use to react accordingly in order to provide solutions to environmental problems. For agriculture, this is especially important, because this industry of social production, like no other, is closely linked to living and non-living objects of the environment. [10-12]. Therefore, in today's conditions, the state of the environment largely depends on ensuring the environmentalization of agrarian production, where environmental and legal requirements are implemented at all stages of agricultural activity. Using the equation of dependence of economic and environmental indicators, it is possible to purposefully control the ecological state of agricultural production in the process of its organization and planning of economic activity.

\section{Conclusions.}

On the basis of the analysis and the obtained results about the influence of environmental factors on the efficiency of agricultural production, we identified that planning of the economic activity of agrarian enterprises and development of the directions of sustainable development of the agrarian sector should be based on priority strategic tasks taking into account the natural resources potential and the ecological state of agriculture.

Therefore, the considered environmental factors can be leveled in the process of organizing production. However, their indexes in showing the economic indicators of agricultural production are different. Therefore, it is very important to determine the degree of influence of each of the factors or their groups on the efficiency of agricultural production through scientifically sound methodological techniques and approaches.

\section{Bibliography}

1. Kolmykov V.F., Kazakevich V.I. (1998). The influence of spatial environmental factors on the results of production activities of agricultural enterprises. Maintain the National Academy of Sciences Belarusi: Series of Agrarian Sciences, vol. 2, pp. 54-58. [in Russian].

2. Shkuratov O.I. (2014). Analysis of the impact of environmental factors on the efficiency of agricultural production. Ekonomika pryrodokorystuvannia i okhorona navkolyshn'oho seredovyscha: [zb. nauk. pr.], pp. 42-44. [In Ukrainian].

3. Baliuk, S.A., Kucher A.V. (2015). Ratsional'ne vykorystannia gruntovykh resursiv i vidtvorennia rodiuchosti gruntiv: orhanizatsijno-ekonomichni, ekolohichni j normatyvno-pravovi aspekty [Rational use of soil resources and reproduction of soil fertility: organizational and economic, environmental and regulatory aspects]. NNTs «Instytut gruntoznavstva ta ahrokhimii im. O.N. Sokolovskoho»; za red. S.A. Baliuka, A.V. Kuchera. Kharkiv: Smuhasta typohrafiia. 426 s. [In Ukrainian].

4. Haraschenko T.V. (2013). Ecological-economic assessment of the impact of the agro-landscape organization of the territory on the efficiency of agricultural production. Zbalansovane pryrodokorystuvannia, vol. 4, pp. 26-30. [In Ukrainian].

5. Karpishchenko O.I., Ksenofontova M.M. (2004). Ahroekosystemy: problemy stiikoho rozvytku [Agroecosystems: problems of sustainable development]. Sumy: VAT «Sumska oblasna typohrafiia vydavnytstvo «Kozatskyi val». $185 \mathrm{~s}$. [In Ukrainian].

6. Krasnjanskaja E.V. (2011). Influence of the composition and correlation of lands on the ecological state of the territory of the Voronezh region. Vestnik Voronezhskogo gosudarstvennogo agrarnogo universiteta, vol. 1, no. 28, pp. 196-199. [in Russian].

7. State Statistics Service of Ukraine (2017). "Sil's'ke hospodarstvo Ukrainy 2016. Statystychnyj zbirnyk" [Agriculture of Ukraine 2016. Statistical yearbook]. Derzhkomstat. Kyiv. 386 s. [in Ukraine].

8. State Agency for Land Resources of Ukraine (2017), "Derzhavnyj zemel'nyj kadastr Ukrainy (stanom na 1 sichnia 2017 r.). Zbirnyk analitychnykh materialiv" [State Land Cadastre of Ukraine (as of January 1, 2017). Collection of analytical materials]. Kyiv: Derzhzemahenstvo. 117 s. [in Ukraine]. 
9. State Statistics Service of Ukraine (2017). "Vnesennia mineral'nykh ta orhanichnykh dobryv pid urozhaj sil's'kohospodars'kykh kul'tur u 2016. Statystychnyj zbirnyk" [The introduction of mineral and organic fertilizers for crop crops in 2016. Statistical yearbook]. Kyiv: Derzhkomstat. 52 s. [in Ukraine].

10. Savkin V.I. (2011). Kontseptual'nye osnovy ekologicheskogo menedzhmenta v agrarnom sektore ekonomiki: monogr [Conceptual foundations of environmental management in the agrarian sector of the economy]. Orel: OGAU. 184 s. [in Russia].

11. Daly H.E. (2007). Ecological Economics: Principles and Applications, Washington: Island Press. $385 \mathrm{p}$.

12. Jiang Mingjun (2012). Introduction to Ecological Safety World Affairs Press. World Affairs Press. $491 \mathrm{p}$. 